\title{
Meer bevoegdheden voor de Inspectie? Over 'zwarte' lijsten en andere sancties
}

De Wet BIG biedt de IGZ de mogelijkheid om een spoedprocedure bij de tuchtrechter aan te spannen. De tuchtrechter heeft de mogelijkheid een BIG-geregistreerd beroepsbeoefenaar onmiddellijk gedeeltelijk of volledig de bevoegdheid om in het BIG-register ingeschreven te staan te ontzeggen en kan bij wijze van voorlopige voorziening een schorsing van de inschrijving in het BIG-register opleggen, indien het belang van de bescherming van de individuele gezondheidszorg zulks vordert. Verder kan de IGZ op basis van artikel 87 a Wet BIG of op basis van artikel $7 \mathrm{KWZ}$ een schriftelijk bevel c.q. aanwijzing (laten) geven aan een beroepsbeoefenaar of instelling als er geen sprake is van verantwoorde zorg. Een grondige analyse van de vraag waarom de IGZ deze bevoegdheden niet of relatief weinig gebruikt wordt tot nu toe node gemist, ook in een recent aan de IGZ en de Minister van VWS uitgebracht advies, ${ }^{\mathrm{I}}$ waarin een scala aan interessante (wetgevende) suggesties wordt gedaan om de IGZ meer bevoegdheden te geven. ${ }^{2}$ Het advies heeft mijns inziens echter te weinig oog voor de rechtsbescherming van de individuele beroepsbeoefenaar. Ten aanzien van dit laatste springen twee punten in het oog. In de eerste plaats wordt geadviseerd dat meldingen aan de IGZ voor de zorgaanbieder/beroepsbeoefenaar op wie de melding betrekking heeft anoniem moeten kunnen blijven en in de tweede plaats dat in een besloten gedeelte van het BIG-register alle tuchtrechtelijke maatregelen en disfunctioneren worden aangetekend. Dit besloten gedeelte zou voor derden met een gerechtvaardigd belang, onder wie werkgevers/zorginstellingen en zorgverzekeraars, toegankelijk dienen te zijn. Ook gegevens van meer dan vijf jaar oud kunnen later via een historisch archief weer gekoppeld worden. Deze voorstellen schieten mijns inziens hun doel voorbij en zijn een uiting van 'low trust'. ${ }^{3}$ Anonieme meldingen kunnen een bron zijn van verdachtmakingen en zwartmakerijen zonder dat daar een grond voor is. Tegen de tijd dat dat blijkt is het vaak al te laat en zijn de beroepsbeoefenaar en zijn carrière beschadigd. Het registreren van tuchtrechtelijke maatregelen of uitkomsten van functioneringsonderzoek waarop niet het stempel van laakbaarheid drukt, staat voorts niet in verhouding tot het 'delict'.

Aanbevelingswaardig zijn wel de aanbevelingen tot een actievere samenwerking en niet-vrijblijvende toetsing van de raad van bestuur, medische staf en maatschap/ vakgroep in het kader van hun gezamenlijke verantwoordelijkheid voor kwaliteit.

\section{W.R. Kastelein}

\footnotetext{
I. J. Legemaate, Verantwoordelijkheid nemen voor kwaliteit. Advies naar aanleiding van de aanbevelingen van de Inspectie voor de Gezondheidszorg in haar rapport over de zaak van de Twentse neuroloog, Amsterdam: Vrije Universiteit I2 mei 2009.
}

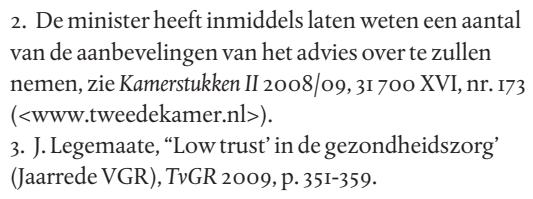

2. De minister heeft inmiddels laten weten een aantal van de aanbevelingen van het advies over te zullen nemen, zie Kamerstukken II 2008/o9, 3I 70o XVI, nr. 173 (<www.tweedekamer.nl>).

3. J. Legemaate, “Low trust' in de gezondheidszorg' (Jaarrede VGR), TvGR 2009, p. 35I-359. 